\title{
An Account of a Leprosy Village and its Place in the Treatment of Leprosy*
}

\author{
A. B. CROSS \\ Medical Department, Honiara, British Solomon Islands Protectorate
}

\begin{abstract}
The history and working of a leprosy village in the British Solomon Islands are described. Treatment carried out in the village is reviewed. The rôle of the leprosy village is discussed. The leprosy village described is a success in that it gives adequate treatment, saves money and, most important, the inhabitants are happy. A competent and respected person in charge of the village is essential. He should have a basic nursing training. The village must be adequately supervised.
\end{abstract}

\section{Introduction}

The Solomon Islands comprise an archipelago stretching in a south-easterly direction from New Guinea and spreading over 900 square miles (1 450 square $\mathrm{km}$ ) of the Pacific Ocean. One of the 6 larger islands in the group is Malaita; like its neighbours, it has a mountainous spine and is covered with dense tropical rain forest which, at intervals, drops down to the coastal reefs. The island is 140 miles $(225 \mathrm{~km})$ long and has a maximum width of 20 miles $(32 \mathrm{~km})$. The population of 52,000 , which is all Melanesian, lives in scattered villages both in the interior and on the coast. The average annual rainfall in Malaita is 125 in $(318 \mathrm{~cm})$. In the only 2 leprosy surveys done on Malaita, the prevalence of leprosy was approximately $1 \%$ (Ross Innes, 1937; Drake, 1963). A third survey is now being carried out.

The Government Administration centre for Malaita District is at Auki, which lies on the island's north-west coast. The leprosy village of Ombufau is 4 miles $(6.4 \mathrm{~km})$ from Auki town and $3 \frac{1}{2}$ miles $(5.6 \mathrm{~km})$ from the Government District Hospital. The hill-top setting of Ombufau is very picturesque, with a magnificent view across the sea to the neighbouring islands. However, the village is not easily accessible. It can be reached either by foot along a bush path from Auki or by Landrover up a very rough $2 \frac{1}{2}-$-mile $(4 \mathrm{~km})$ track which becomes impassable in bad weather.

\section{History}

Ombufau village was started in 1941, just before World War II came to the islands. In this year a 22-year-old policeman, P.C. Mahlon Moite'e, of the British Solomon Islands Constabulary, on being found to have leprosy, was discharged from the Force. After initial treatment, he returned to his village in an area of Malaita where there has always been a high prevalence of leprosy. After a short

* Received for publication November, 1972. 
period at home, he decided to become a dresser with the idea of helping others who had contracted leprosy. He discussed the matter with Dr Hugh Wheatley, one of the first Solomon Islanders to qualify in medicine. The latter readily agreed to have Mr Moite'e trained, and this was undertaken at the District Hospital. It was during this period that Dr Wheatley and Mr Moite'e conceived the idea of a leprosy village in the Auki area. At that time the only permanent settlement for leprosy patients was at the Hospital of the Epiphany at Fauambu, 15 miles $(24 \mathrm{~km})$ from Auki. This hospital, which is run by the Melanesian Mission, still has a small leprosy settlement.

On completion of his training as a dresser, Mr Moite'e returned to his village and gathered together the leprosy families in the area. After discussion most of them decided that they would like to form a community and live together at a place where medical help was at hand. A local landowner provided land at Ombufau for the village and its gardens. This land has now been inherited by Moite'e's son, John Quaeifiae, who unfortunately contracted leprosy himself and now lives at Ombufau with his family. Dr Wheatley gained Government approval for the scheme and the patients themselves cleared the land and built, in bush materials, houses for themselves, a sturdy clinic, and two dormitories. The village, which had a fluctuating population of about 40, soon became permanently established and entirely self-supporting.

Life at Ombufau was disrupted when World War II came to the Solomons. During this time Dr Wheatley died and, as a result, the village ran solely under $\mathrm{Mr}$ Moite'e's care for several years. Although no military action took place at Ombufau itself, Japanese forces were in the vicinity. After the war years responsibility for the maintenance of the village and for Mr Moite'e's salary was assumed by the Malaita Council, and medical supervision was re-established by the Government Medical Department.

As might be expected, the fortunes of the village have fluctuated over the years with the inevitable changes of staff and the waxing and waning of enthusiasm for leprosy work at both medical and council levels. Thanks to Mr Moite'e's personality and dedication, and despite some damage to his hands and feet the village has kept going. In 1963 he was honoured with the Western Pacific High Commissioner's Badge.

In 1960 the Lepers' Trust Board Inc. of New Zealand, which has given generous financial support and shown much interest in the problems of leprosy in the Pacific, rebuilt the clinic and dormitory block in permanent materials and installed a water supply. Recently the Board financed repairs to the clinic and provided new water storage tanks. Since the beginning of 1969, medical supervision of Ombufau has been assured by regular monthly visits by government medical staff.

\section{Description}

Ombufau is situated on top of a $500 \mathrm{ft}(152.4 \mathrm{~m})$ hill with good surrounding agriculture land. The village is dominated by its Rural Health Clinic, a building in permanent materials, $40 \mathrm{ft}$ long by $22 \mathrm{ft}$ wide $(12.2$ by $6.7 \mathrm{~m})$-see Fig. 1 .

The entrance to the clinic leads into a central reception or waiting area, and on either side are two large rooms, one of which is used as a dormitory by females, the other as a recreation centre. Behind the reception area are two smaller rooms, one of which is a store for basic medical equipment and provisions and the other a 


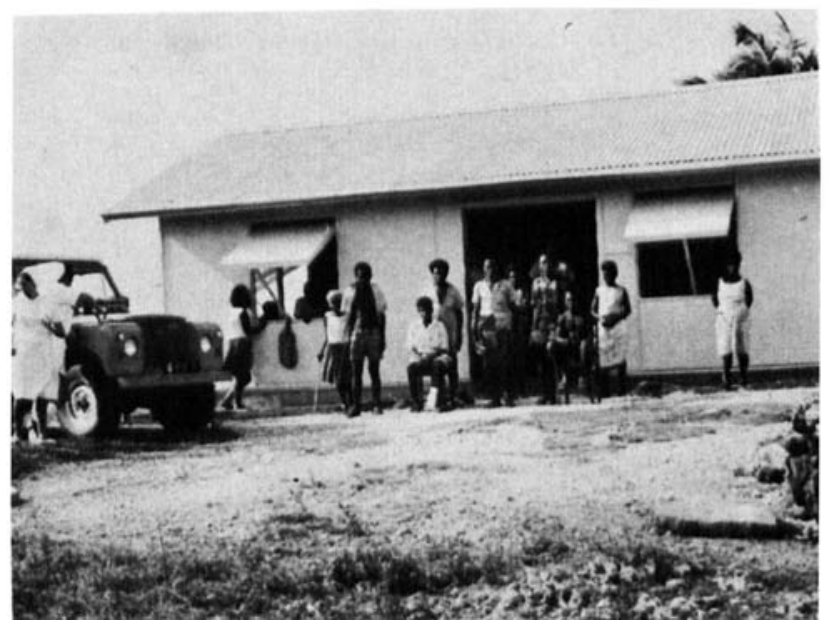

Fig. 1. The Rural Health Clinic at Ombufau.

consulting and treatment room. Behind the clinic is a permanently constructed single-roomed dormitory $30 \mathrm{ft}$ by $20 \mathrm{ft}(9.2$ by $6.1 \mathrm{~m})$ with accommodation for 12 male patients (Fig. 3). Scattered around these two buildings are 11 typical Solomon Island leaf houses; these have been built by the villagers for their families.

The main water supply to the village has been installed by the Lepers' Trust Board Inc. of New Zealand, and consists of 4 large fibre-glass tanks which supply water to the clinic, the dormitory and a tap in front of the clinic where villagers collect water for domestic use (Fig. 3). The Lepers' Trust Board has also built an ablution block and pit latrines to encourage a high level of hygiene. Around the

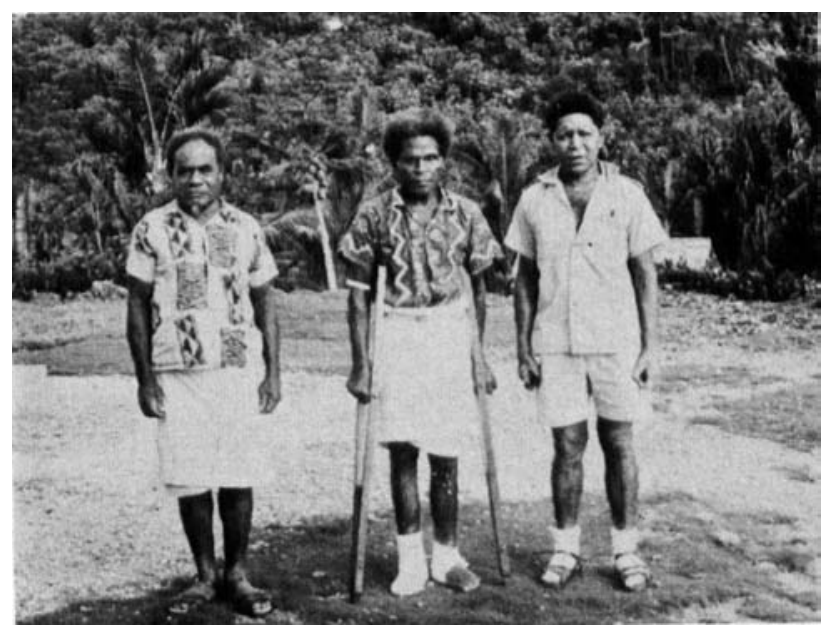

Fig. 2. Three ex-policemen: right, Mr Moite'e in charge of Ombufau; left, Mr Satafana, his assistant; and centre, a patient with trophic ulcers in a plaster boot. 


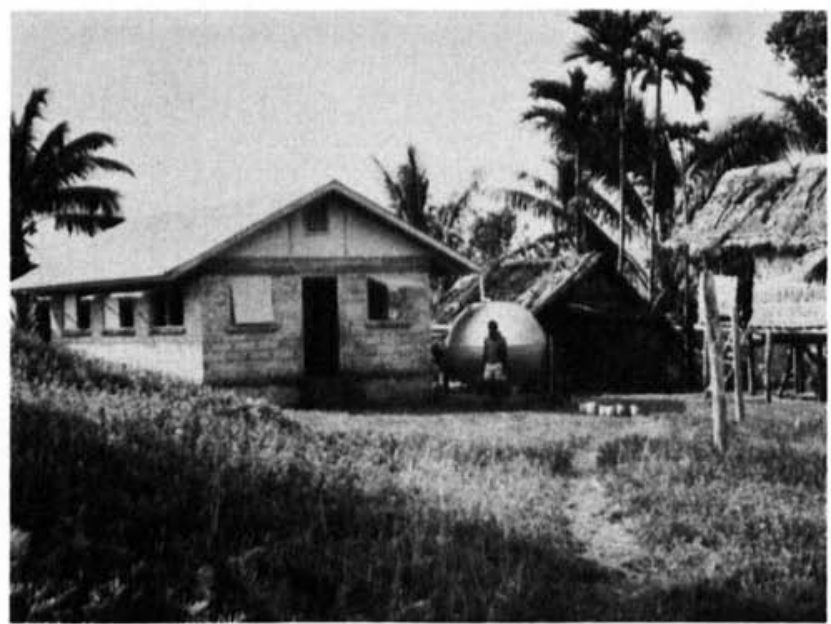

Fig. 3. The dormitory block, fibre-glass water tank, and village houses at Ombufau.

village are gardens which are worked communally. The garden produce and the rearing of livestock make the village practically self-supporting.

\section{Aims of the Village}

These are: (1) To offer a normal village life in a home-like environment to leprosy sufferers and their families. (2) To accommodate patients who are undergoing short-term treatment such as the healing of trophic ulcers. (3) To provide an opportunity to educate patients in their disease, and particularly in the care of their hands and feet. (4) To provide facilities for investigation and treatment at low cost. (5) To provide a refuge for patients who are rejected by their villages-fortunately an uncommon happening in the Solomon Islands.

\section{The Work of the Village}

The village is under the vigilant care of $\mathrm{Mr}$ Moite'e, who is officially the Council Dresser for the clinic; he also acts as the village Headman. He is held in great respect by the village and by all those in the area served by his clinic. His police training has helped to mould him as a leader. His assistant is Mr Satafana, also an ex-policeman, who contracted leprosy in his youth (see Fig. 2).

The clinic opens every morning for the administration of anti-leprosy drugs and for any other medical treatment required. Serious problems, including leprosy reactions, are referred to the District Hospital. The only leprosy drugs administered by Mr Moite'e are those ordered by medical of ficers. No maternity work is undertaken at the clinic.

On the first Thursday of every month the clinic is visited by a Government Medical Officer and the Government physiotherapist. Not only do the village patients attend, but also leprosy patients from the surrounding district. Treatments are reviewed and all hands and feet examined. Neuropathic ulcers of the feet are treated by plaster of Paris boots, and the patients are given crutches. 
Owing to weather conditions, short leg walking plasters have proved impracticable. Footwear, which is supplied by the Lepers' Trust Board of New Zealand, is distributed to all patients who need it. This consists in most cases of durable plastic sandals or canvas basketball boots, some of which are modified to accommodate foot deformities.

During these visits, the physiotherapist holds an exercise session. Encouragement is given to continue the simple exercises in her absence. Every opportunity is taken to teach care of the hands and feet during these routine visits. Patients who are having their drug dosage increased stay in the village for a short time; this has proved satisfactory and popular. Some food is provided by the Government to help feed the short-time patients billeted in the village.

Apart from the medical work described, village life goes on as in any other Solom on Island community, with the men building the houses and preparing new gardens, while the women do the cooking, collect firewood, and tend the gardens.

\section{Results}

Visits have continued every month for 3 years. The statistics that follow deal with the period July, 1969 to June, 1972 inclusive.

TABLE 1

Leprosy patients seen at Ombufau

\begin{tabular}{ll}
\hline Leprosy patients living at Ombufau & 16 \\
Patients temporarily housed at Ombufau & 22 \\
Leprosy patients attending from the surrounding area & 31 \\
\multicolumn{1}{c}{ Total } & 69
\end{tabular}

The average number of patients seen each month was 31 , the total number varying from 15 to 47 . Low attendances were accounted for by heavy rain which made the journey to Ombufau difficult.

The patients who were admitted on a temporary basis came from all over Malaita. The commonest cause for admission was trophic ulcers. Other causes included patients awaiting the confirmation of the diagnosis of leprosy, the establishment of drug therapy, and the general care of the hands and feet. The average stay of these patients was 12 weeks.

TABLE 2

Treatment carried out for leprosy patients

\begin{tabular}{lr}
\hline Patients established or re-established on leprosy drugs & 13 \\
Patients accommodated for the investigation of leprosy & 8 \\
Trophic ulcers treated with plaster of Paris bandages & 37 \\
Burns treated & 11 \\
\hline
\end{tabular}

All adult leprosy patients were given a weekly dose of $200 \mathrm{mg}$ of dapsone; "burnt out" cases were also given treatment since this simplified the administration of drugs. Patients newly diagnosed were given treatment initially in the District Hospital and they tolerated the drugs well. They were transferred to Ombufau, where the dosages were increased. When the dose had been increased to the maintenance level, patients coming from a distance returned home. 
Eight patients were accommodated in the village for further investigation of possible leprosy. The delay in diagnosis was due to the fact that skin biopsy specimens have to be sent to New Guinea for a histo-pathological report, and this takes approximately 3 weeks. Of the 8 biopsies, 5 were positive and 3 negative. As all confirmed leprosy patients were being given anti-leprosy drugs, there would appear to be little risk to the 3 patients who were found not to have leprosy.

Of 43 feet with neuropathic ulcers, 37 were treated with plaster of Paris boots. Treatment of these ulcers in the village was satisfactory in that all the ulcers eventually healed, although a few later recurred and plasters had to be reapplied. Most of the ulcers that had to be treated in plaster were seen in the first year of the survey.

A few small ulcers were treated by dressings alone, a procedure found to be adecuate.

\section{Discussion}

A though very little about leprosy villages appears in the literature they do in fact exist in varying forms in many parts of the world. Opinions differ as to their value.

After World War II four leprosy villages were started in various parts of the Solomon Islands. After running fairly well, one was washed away by a cyclone in 1967 and the inhabitants returned to their original villages. Two others have unfortunately fallen into disuse, owing to lack of support and a suitably trained person in charge. Ombufau alone continues to function.

In 1952, C. J. Austin visited Ombufau on Malaita and a leprosy village, now completely run down, at Sidu on the island of Santa Ysabel. He felt that there was certainly a place for leprosy villages of this kind.

J. N. Rodriguez visited the Solomon Islands in 1957 as a World Health Organization consultant and while there inspected Ombufau. He, like Austin, felt that Ombufau was playing an important rôle in the management of leprosy on Malaita. However, he emphasized that such villages must be properly supervised.

In 1964 R. V. Wardekar also visited the Solomon Islands as a World Health Organization consultant and saw some of the leprosy villages. He stated in his report that "it is doubtful if these (leprosy) villages are serving any useful purpose".

It is clear from personal experience in the Solomon Islands that while a leprosy village can serve a useful rôle, it must be in the charge of a responsible person with at least a basic nursing training. He must have an interest in leprosy, and his work should be supervized regularly by a doctor. One of the advantages of Ombufau is that it is easily accessible from the district headquarters, allowing medical staff to visit the village and return to base in one day; two of the other villages failed because of their remote location. Ombufau has been fortunate in that it includes a Health Clinic.

Adequate finance is always a problem in any leprosy programme. The Solomon Islands' Government finds it more economical to house patients in a leprosy village than in a busy district hospital, or to incur the expense of sending them (and perhaps their families) to the Government Leprosarium on another island. Ultimately the factor that determines the success of such a village is whether or not the inhabitants are content. The people of Ombufau always appear cheerful, and the fact that many of the neighbouring leprosy patients attend the monthly 
visits shows that the village is an acceptable centre. The patients receive better individual attention in a village concerned mainly with leprosy problems than in an acute general hospital.

Health Education at Ombufau appears to have been successful in that the patients now want to have footwear and are quick to present their worn-out shoes for replacement. Patients who formerly neglected their hands and feet are now more careful, knowing that they will be inspected each month.

The patients appear to have lost much of the dread of leprosy in recent years. This is partly due to the fact that they realize they can live happily in a village setting rather than be incarcerated for many years in an institution-a most important factor in making leprosy villages successful.

\section{Acknowledgements}

I wish to thank Sister Jane Burleigh, S.M.S.M., Government Physiotherapist, and Mr Mahlon Moite'e, the Dresser at Ombufau, who have done much to make the village a success; and Dr J. D. Macgregor, O.B.E., Director of Medical Services, British Solomon Islands Protectorate, for permission to publish.

\section{References}

British Solomon Islands Protectorate (1970). Annual Report, pp. 87-89. London: H.M.S.O.

Austin, C. J. (1952). Leprosy in the British Solomon Islands Protectorate, p. 4. South Pacific Commission. Technical Paper 27.

Drake, A. H. (1964). Report on a field Leprosy Survey conducted on Malaita, British Solomon Islands, Table D. British Leprosy Relief Association (LEPRA).

Rodriguez, J. N. (1957). Report on Leprosy in the British Solomon Islands Protectorate, p. 7. W.H.O. Regional Office for Western Pacific.

Ross Innes, J. (1937). Report of Leprosy Survey of the British Solomon Islands Protectorate, p. 67. Government Printer of His Britannic Majesty's High Commission of the Western Pacific-Suva, Fiji.

Wardekar, R. V. (1964). Assignment Report, p. 4. W.H.O. Regional Office for the Western Pacific. 